\title{
THE SPECIAL SEIZURE
}

\author{
Gh. Diaconu
}

\section{Gheorghe Diaconu}

Law Department, Faculty of Juridical and Administrative Sciences, University of Piteşti, Piteşti, Romania *Correspondence: Gheorghe Diaconu, Court of Appeal Piteşti, 22 Victoriei St., Piteşti, Romania

E-mail: gheorghe.diaconu@just.ro

\section{Abstract}

The special seizure is a safety measure privative of goods and it consists in the fact that the goods or the values that belong to the person that commited a criminal deed, they are unnaturally passed in the state's patrimony. The possession of these goods or values, because of their nature or because they are related to the committed deed, it presents the danger of perpetration other deeds provided by the penal law.

Keywords: seizure, state of danger, goods submitted to the seizure.

\section{Introduction}

The special seizure is a penal sanction which belongs to the category of safety measures that are meant to eliminate a state of danger and to prevent the perpetration of the deeds provided by the penal law.

As it's a measure privative of goods, it consists in the fact that the goods or the values that belong to the person that commited a criminal deed, they are unnaturally passed in the state's patrimony. The possession of these goods or values, because of their nature or because they are related to the committed deed, it presents the danger of perpetration other deeds provided by the penal law; at the same time, if the goods were let in the doer's possession, then they would represent a danger for the rule of law.

\section{Notion}

The safety measure of special seizure is a measure privative of goods and it consists in the fact that the goods or the values that belong to the person that commited a criminal deed, they are unnaturally passed in the state's patrimony. The possession of these goods or values, because of their nature or because they are related to the committed deed, it presents the danger of perpetration other deeds provided by the penal law.

The relevant provisions are found in article 118 of the Penal Code.

The safety measure of special seizure distinguishes from all the other safety measures by the specific of its material incidence. Thus, while all the other safety measures regard the persons, respectively the person who committed a deed established by the penal law, on the contrary, the special seizure concerns certain goods and taking this measure is conditioned by the state of danger that these goods may represent (objective dangerousness).

In the juridical doctrine it has been stated the opinion according to which the state of danger has to be considered not only in relation to the goods submitted to special seizure, but also in relation to the doer's person, in the sense that it prevents not only the perpetration of new criminal deeds by their owner but also any person's guilty conduct that is willing to break the penal law ${ }^{1}$.

\footnotetext{
${ }^{1}$ C. Dărîngă, Privire generală asupra măsurilor de siguranță, "Revista Română de Drept (R.R.D.)" Review number 1/1967, p. 48.
} 
The justification of the special seizure lies in the social jeopardy, in the state of danger that these goods would present if they were let at the free disposal of the persons and thus they could be utilized in order to commit criminal deeds.

Consequently, some of these goods are dangerous by their nature (for instance: arms, explosive substances, narcotic substances), other goods become dangerous by the destination or by the use they were given (for instance: breaking tools, proper keys, devices for the coinage offence). There are also certain goods which are dangerous because of their illicit provenance and because they would represent a permanent incitement to commiting offences if they were let in the possession of the persons that own them (for instance: the posession of the false coin, the possession of counterfeit goods and of artisanal arms). Even more, the jeopardy or the state of danger exists in the case of the goods which are received as a payment for the perpetration of offences (for instance: the money given by the instigator to the author of the murder or the money given as bribe and any other benefits that are received as a reward for commiting an offence).

If these things were let to free circulation among the persons, then it will exist the possibility that they may be utilized for the perpetration of other criminal deeds. For this reason, the measure of special seizure has to be taken in order to eliminate this danger ${ }^{2}$.

This danger appears as a serious fear that the things considered as dangerous to be kept, if they were let in the doer's possession they could serve for the perpetration of other deeds provided by the penal law or they could represent an easy mean utilized in order to get illicit benefits.

\section{Conditions}

The safety measure of special seizure can be enforced only when the following conditions are fulfilled:

\section{a. The doer has committed a deed provided by the penal law}

Usually, the special seizure can be enforced no matter if the committed deed is only stipulated in the penal law or if it represents an offence.

However, in the case of the second category of goods (the goods utilized to commit an offence; the goods made with the purpose to be utilized at the perpetration of an offence, according to article 118 letter b. and c. of the Penal Code), the special seizure can be taken only if these goods are the result of the committed offence. Even in these cases, the enforcement of a punishment is not necessary in order to take the measure of special seizure ${ }^{3}$.

The intervention of some causes of non-punishing doesn't affect the special seizure's enforcement. Consequently, if an offence was committed, the seizure of the good can be disposed even if the offence was amnestied ${ }^{4}$ or it intervened the prescription of the criminal liability ${ }^{5}$ or the defendant's death ${ }^{6}$ or if it exist a cause of non-punishing ${ }^{7}$ or any other cause that may involve the cessation of the penal law suit ${ }^{8}$.

But, the special seizure cannot be enforced if the offence was disincriminated and if the disincriminated deed represents a contravention and the seizure is established for it, then the court will inform the competent legal bodies in order to ascertain the contravention and to take the legal measure of seizure 9 .

\section{b. The existence of a state of danger}

\footnotetext{
${ }^{2}$ R. Chiriță, Câteva considerații in legătură cu temeiul juridic al aplicării măsurilor de siguranță, "Dreptul" Review, number 1/1999, p. 51.

${ }^{3}$ V. Papadopol, Confiscarea specială in practica judiciară, R.R.D. number 5/1983, p. 32.

4 The Supreme Tribunal, Penal Decision number 1647/1971, “Culegere de decizii", 1971, p. 362.

${ }^{5}$ The Supreme Tribunal, Penal Decision number 614/1984, R.R.D. number 2/1985, p. 74.

6 The Tribunal of Timis, Penal Decision number 696/1980, R.R.D. number 7/1981, p. 47, annotated by V. Dobrinoiu and N. Cornea.

${ }^{7}$ The Supreme Tribunal, Penal Decision number 841/1980, in “Culegere de decizii”, 1980, p. 310.

${ }^{8}$ The Supreme Tribunal, Penal Decision number 945/1980, in “Repertoriu” number 2, p. 73.

${ }^{9}$ The Supreme Tribunal, Penal Decision number 3622/1972, Repertoriu number 1, p. 228.
} 
The existence of a danger state represents not only the condition but also the reason of taking this safety measure. It consists, as we said before, in the danger revealed by the committed deed and in the fear that to let free the seizable good in the doer's possession it may serve to the perpetration of other deeds stipulated in the penal law.

In the juridical doctrine, there have been stated many opinions related to the estimation of the state of danger which is necessary in order to enforce the special seizure.

According to the first opinion, the state of danger is always presumed if the good belongs to those categories enumerated by article 118 of the Penal Code ${ }^{10}$.

Another opinion states that if the possession of the good, even if the good is enumerated by article 118 of the Penal Code, if it doesn't present any social danger, then it won't be seized and the danger's estimation belongs to the court ${ }^{11}$.

We consider that the latter opinion is correct and also this opinion was accepted by the case-law ${ }^{12}$. Thus it was established that are not submitted to the special seizure the sums of money that the doer obtained by a useful social work as a consequence of the revaluation of some objects made by the illegal exercise of a profession.

\section{c. The court's estimation that by taking the measure of special seizure, the state of danger is eliminated}

This condition derives from the goals of the safety measures stated by article 111 of the Penal Code, respectively the elimination of the state of danger.

Consequently, the measure of special seizure is taken whenever the court establishes that is imposed in order to remove the dangerous state for the society by keeping the possession of the confiscable good.

In the other situations, even if the good served or it was meant to serve for the perpetration of an offence, it may not be seized if the doer combats the existence of a dangerous state. For instance, we consider that the special seizure is excluded in the situation when the seized goods got into a bona fide interested person's property, in an onerous mode, because in the first place, he benefits by the property presumption established by article 1909 of the Civil Code of 1864 and in the second place, he doesn't belong to that category of passive individuals to whom the safety measures are enforced, because only the persons that committed deeds provided by the criminal law belong to this category, according to article 118 of the Penal Code. Similarly, the court can state that it's not necessary to seize the sums of money that the doer obtained by the exercise of a profession in other conditions than those legally established, if the goods are the result of a social useful work (for instance, the money obtained by the one who exercised the bootmaker's trade, without a legal authorization) $)^{13}$.

\section{Content}

As a measure privative of goods, the special seizure consists in the fact that the seizable good is taken out from the patrimony of the person who owns it and it is passed in the state's property.

But, the special seizure generates effects in rem because is taken by considering certain goods, respectively it generates effects for any person that has the seized goods and that is obliged to hand over them to the judicial bodies. In the latter case, the third party that has confiscable goods is introduced in the criminal trial, under the sui generis quality of third holder $^{14}$.

If the goods submitted to seizure are not found, then money and goods are confiscated up to their amount (article 118 paragraph 4 of the Penal Code).

The special seizure has the character of a penal sanction and not of a civil compensation. Consequently, the one who gave a sum of money to the offender (sum which

\footnotetext{
${ }^{10}$ S. Aragea, Confiscarea specială in practica judiciară, Pro lege number 1/1991, p. 104.

${ }^{11}$ V. Papadopol, Confiscarea specială in practica judiciară, op. cit., p. 36.

12 The Supreme Tribunal, Penal Decision number 464/1978, R.R.D. number 3/1969, p. 41.

${ }^{13}$ The Supreme Tribunal, Penal Decision number 473/1978, R.R.D. number 8/1978, p. 67.

${ }^{14}$ The Supreme Tribunal, Guidance Decision number 3/1973, R.R.D. number 6/1973, p. 97.
} 
was seized) in order to determine him to commit an offence, then he cannot claim a compensation instead of the sum that he had given ${ }^{15}$.

The special seizure's character of penal sanction excludes the possibility of a solidary obligation which is specific to many offenders' liability for the prejudice caused by the offence. Therefore, the minor's parents couldn't be obliged to pay solidary with the minor the pecuniary equivalent of the goods submitted to the special seizure ${ }^{16}$; in the same way, if an offence was committed in penal participation and the offence's benefit was divided among the participants, they cannot be obliged to pay solidary the sums that represent the totality of the seized sums, but each of them will pay depending on the part that he got ${ }^{17}$; also, it cannot exist a solidary obligation for the payment of the values which are susceptible of special seizure $^{18}$.

\section{Categories of goods that are submitted to the special seizure}

Article 118 of the Penal Code generically enumerates the categories of goods submitted to the safety measure of special seizure. Although they are enumerated in a limited mode, the categories of goods mentioned in the text are wide enough in order to ensure the special seizure's efficiency. These goods are as it follows:

\section{a. The goods made by the perpetration of a deed provided by the penal law}

The goods produced by the perpetration of a penal deed are those goods which are the result of the action that forms the material element of the committed deed, as: false banknotes; counterfeit credit titles; the arms made in an artisanal mode; adulterated food, beverages or medicines; explosive matters ${ }^{19}$ and others.

There are considered as goods made by the committed offence those that illicitly had got a certain quality, a certain position in fact which they could get only by illegal means as it would be, for instance, the goods inserted by contraband in the state, beverages, cigarettes, medicines that contain an important dose of narcotics prepared on the base of an abusive medical prescription and others ${ }^{20}$.

Also, there are considered as goods produced by the penal deed, the sums of money that were obtained from the goods traffic as it would be, for instance, the sums of money obtained by the sale of the false banknotes and others.

According to article 118 of the Penal Code, "the good" is defined as any object that has both an external physical existence and a value which can be economically valuated and that is susceptible of appropriation.

Depending on the safety measures' goals (the elimination of the state of danger and the prevention of the perpetration of new offences), there cannot be considered goods produced by the perpetration of a deed provided by the penal law, those goods obtained by the offender from other offenders by the perpetration of such deeds (as it would be, for instance: delapidated sums of money, documents which were purloined by a spy, sums of money obtained by threatening or by blackmail and others) because these goods are returned to the one who incurred a damage.

By the mode in which article 118 letter a. of the Penal Code is drawn up (which represents the relevant provisions for the special seizure of the goods produced by the deed provided by the penal law) it results that in order to dispose their seizure it's not necessary that the deed should be an offence but it's enough the deed's penal character (for instance, adulterated foods that were sold by an irresponsible person).

\footnotetext{
${ }^{15}$ The Supreme Tribunal, Penal Decision number 2559/1972, R.R.D. number 2/1973, p. 169.

${ }^{16}$ Tribunal of Bucharest, Penal Decision number 2279/1984, R.R.D. number 3/1986, p. 78.

${ }^{17}$ The Supreme Tribunal, Penal Decision number 276/1981, R.R.D. number 11/1981, p. 57.

${ }^{18}$ The Supreme Tribunal, Penal Decision number 448/1977, R.R.D. number 12/1977, p. 44.

${ }^{19}$ The Tribunal of Bucharest, Penal Decision number 298/1983, Repertoriu number 3, p. 158.

${ }^{20} \mathrm{M}$. Vasile, Aspecte particulare in materia confiscării speciale in ceea ce priveşte cazurile de aplicare, "Dreptul” Review, number 3/2002, p. 134.
} 


\section{b. The goods that were utilized in any mode for the perpetration of an offence}

The relevant provisions can be found in article 118 letter b. of the Penal Code and from the content of the legal text it results that the following conditions have to be fulfilled in order to take the measure of special seizure:

- the good had to be utilized for the perpetration of an offence (for instance, the knife or the arm with which the murder was committed, the key utilized for breaking into a place, the axe with which a good was destroyed, the sporting gun utilized at poaching and others). Consequently, if the deed at which perpetration the good was utilized it doesn't represent an offence and it's only a deed provided by the penal law, then the good couldn't be seized ${ }^{21}$;

- the good that was utilized at the perpetration of an offence it has to be the offender's property. If the good doesn't belong to the offender but it's other person's property, it would be confiscated only if the proprietor knew the goal of its illicit use; on the contrary, only the pecuaniary equivalent would be seized (article 118 paragraph 3 of the Penal Code). Thus, as we exemplify, the following goods are not seized: the knife taken by the offender from the table in the local where the murder was committed; the torch utilized by the doer and which was purloined or borrowed from a friend; the camera utilized by the spy and which it was borrowed from another shop. Even if the utilized good belongs to other person, it will be seized if the good by itself it presents social danger as, for instance, the case in which the offender borrows a fishing net and he poaches with it.

If the good utilized for the perpetration of an offence is the offender's and other persons' joint property, the seizure is wholly enforced and the joint owners have to revaluate their rights by a separate civil action ${ }^{22}$.

In the case-law it was stated that the seizure of the vehicle it cannot be disposed if it was accidentally utilized for the theft of woods from the forest, in value of 4000 lei and the remaining in the doer's possession doesn't present any social danger ${ }^{23}$; in the same mode, if the vehicle wasn't utilized at the perpetration of the offence, but it was utilized to transport cereals that came from repeated purloinings in small quantities, from the doer's home to other place in order that the goods shouldn't be discovered ${ }^{24}$; or the bicycle with which the offender transported a reduced quantity of corn cobs purloined from the enterprise, because the corn cobs' transport could be made without bicycle and the bicycle wasn't especially utilized for the corn's transport but for the offender's movement from his home to the enterprise from which he purloined the corn ${ }^{25}$; the apartment even if it was ocasionally utilized for the practice of the prostitution because it wasn't meant to serve for the perpetration of offences and it hadn't such destination, in an objective sense ${ }^{26}$.

If the good utilized at the perpetration of an offence was alienated by the offender to a bona fide interested person, then the equivalent of the sum it would be seized, respectively the received price, but only if this is not inferior to the goods' real value because, on the contrary, the offender will be obliged to pay a sum that represents its real value.

When the good submitted to seizure has a value which is obviously disproportionate in comparison with the nature and the gravity of the offence, taking into account the offence's consequences and his contribution to it, then a partial seizure is disposed, by pecuniary equivalent (article 118 paragraph 2 of the Penal Code) ${ }^{27}$.

From the rule concerning the seizure of the good that served for the perpetration of an offence, it exists an exception (provided by article 118 paragraph 1, second thesis of the Penal Code). According to this exception, the measure cannot be disposed in the cases of the

\footnotetext{
${ }^{21}$ The Supreme Tribunal, Penal Decision number 1822/1979, Culegere de decizii, 1979, p. 464.

${ }^{22}$ The Supreme Tribunal, Penal Decision number 54/1985, R.R.D. number 7/1986, p. 78.

${ }^{23}$ The Tribunal of Maramureş, Penal Decision number 91/1984, R.R.D. number 11/1984.

${ }^{24}$ The Supreme Tribunal, Penal Decision number 798/1985, R.R.D. number 2/1986, p. 78.

${ }^{25}$ The Tribunal of Bucharest, Penal Decision number 2489/1984, Repertoriu number 3, p. 62.

${ }^{26}$ The Supreme Tribunal, Penal Decision, number 2973/1985, R.R.D. number 12/1986, p. 73.

${ }^{27}$ M. Basarab, Aspecte teoretice şi practice privind confiscarea specială in lumina art. 118, lit. b, Cod penal, Studia Universitatea, Babeş Bolyai, Jurisprudentia XXXII, number 2/1987, p. 73.
} 
offences committed by press. As a consequence, the goods utilized by the journalists that committed offences of insult and slander and others; thus there cannot be seized: the computers, the video equipments, the cameras and other such goods ${ }^{28}$.

\section{c. The goods that were produced, modified or adapted with the purpose of committing an offence}

The relevant provisions can be found in article 118 letter c. of the Penal Code, according to which all the goods that were produced, modified or adapted for the purpose of committing offences they are submitted to the measure of special seizure. Consequently, these goods have to be the "fruits" of an offence; when the committed deed hasn't a penal character (it exists one of the causes that remove the deed's penal character and that are provided by articles 44-51 of the Penal Code), the goods cannot be confiscated.

The goods produced by the perpetration of an offence are those goods that hadn't exist before the committed offence, they exist only owing to the action which forms the material element of the committed deed, as it would be, for instance: false coins, adulterated beverages or foods, the artisanal arms, the manufacture of the pirate compact discs and others $^{29}$.

In the same mode, there are considered as "goods produced" by the offence those goods that got a certain quality, a factual position by the offensive activity as it would be, for instance: the goods obtained by contraband.

In comparison with the "produced goods" that hadn't had an existence before the committed offence, the goods that were modified or adapted and that existed before the perpetration of an offence, but by the offensive activity, an intervention is made over them in order to be utilized at the committed offence, as it would be, for instance: a medicine of which content is modified by the mixture with a dose of morphine in order to become valuable or to be utilized as a drug; or the doubling of a cistern's walls that transported combustible so that the quantity of combustible that existed between its walls it couldn't be noticed or the case when the poacher manufactures various devices (dragnets, fishing net) for catching fishes.

Such goods are submitted to seizure only if they were utilized at the committed offence and only if they belong to the offender.

If the respective goods belong to another person that the offender, the seizure will be disposed only if the goods were produced, modified or adapted by the proprietor himself or by the offender, but with the proprietor's knowledge.

If the goods don't belong to the offender and the person to whom they belong didn't know the goal of their use, then the goods' pecuniary equivalent would be seized (article 118 paragraph 3 of the Penal Code).

Also, if the goods that were "produced, modified, or adapted" cannot be found, then money and goods would be confiscated, up to their value.

Sometimes, although certain goods are the result of a perpetrated offence, they cannot be considered as "produced goods" when they were fraudulently obtained by the offender from other persons as it would be, for instance: stolen or delapidated sums, sums obtained by blackmail, documents purloined by a spy and others; these goods are not seized, but they are returned to the injured person.

\section{d. The goods that were given in order to determine the perpetration of an offence or in order to reward the doer}

There are considered as "goods given" to determine the perpetration of a deed provided by the penal law, those goods which have a patrimonial value (money or other

\footnotetext{
${ }^{28}$ J.F. Popa, Măsura de siguranță a confiscării speciale prevăzută de art. 118 lit. b., Cod penal cu referire specială la confiscarea vehiculelor, "Dreptul” Review number 6/2000, p. 108.

${ }^{29}$ The Tribunal of Bucharest, Penal Decision number 298/1983, Repertoriu number 3, p. 158.
} 
things) that had been offered before to the doer, in order to determine him to commit the respective deed.

The goods given in order "to reward" the doer are those goods with an economic value that are offered as a payment for him, after he had committed the deed.

In both situations, it's not necessary that the deed should represent an offence, but it's enough if it has only a penal character.

The goods given in order to determine the perpetration of a deed provided by the penal law appear as means which indirectly serve for the offence's perpetration because they stimulate the doer's activity.

But only the goods that were actually given to the doer in order to determine him to commit the deed provided by the penal law, they are submitted to the special seizure. Consequently, there cannot be seized the goods promised in order to determine or to reward the perpetration of the deed and the promise was accepted or it wasn't rejected or it wasn't respected afterwards ${ }^{30}$.

If the good was actually given to the doer, then it would be seized even if he hadn't proceeded to commit the deed or if he had denounced to the authorities the offer which it had been made for him, as it would be, for instance the situation when the officer to whom it was given bribe, he denounces this fact and thus the briber is caught ${ }^{31}$.

Also, there are submitted to the special seizure, the goods (money) given in order "to determine" or "to reward" the doer even if the deed remained in the stage of attempt or if the doer committed another deed than the one which was prepared and he cheated the person who gave him the money ${ }^{32}$.

It has no relevance if the goods were given on the initiative of the person who offered them or at the doer's request.

There aren't submitted to the special seizure the goods that were given under the pressure of a constraint, for instance, we mention the situation when the person is constrained to bribe.

e. The goods that were obtained by the perpetration of the deed provided by the penal law

In the sense of article 118 letter e. of the Penal Code, the goods obtained by the perpetration of a deed provided by the penal law, are those goods that came under the doer's hands as a consequence of the totally development of the offensive activity and of the produced result (stolen goods, delapidated money and goods, goods obtained by fraud and others ${ }^{33}$ ); in other words, these goods are "the fruits" of the committed deed.

There are also assimilated to the obtained goods, those goods that took the place of some goods that were initially obtained by the deed provided by the penal law, as it would be the money gained from the sale of the stolen goods or the car which was bought with delapidated money and others ${ }^{34}$, because the substituted goods have the same illicit character regarding their obtaining.

If by the deed provided by the penal law there were obtained sums of money, these are always seized in kind because they have a fungible character.

If the goods obtained by the penal deed (others than the sums of money) are not found in the doer's possession and the person who has them is not known, then the seizure of the equivalent will be disposed.

\footnotetext{
${ }^{30}$ The Supreme Tribunal, Penal Decision number 3074/1985, R.R.D. number 9/1986, p. 74.

${ }^{31}$ The Supreme Tribunal, Penal Decision number 1578/1984, R.R.D. number 10/1985, p. 74.

${ }^{32}$ C. Turianu, I. Mihai, Examen teoretic al practicii judiciare cu privire la aplicarea măsurii de siguranță a confiscării, R.R.D. number 5/1987, p. 126.

33 C. Niculeanu, Confiscarea specială. Sume de bani obținute prin valorificarea bunurilor dobândite prin infracțiune, "Dreptul” Review, number 4/1999, p. 138.

${ }^{34}$ The Supreme Tribunal, Guidance Decision number 3/1973, R.R.D. number 6/1973, p. 97.
} 
If the person who got them is known, the situation is different depending on the fact if there were asked compensations or not, or depending on the interested person's bona or mala fide, in the moment of the obtaining. Thus, in all cases when the injured person requested the restitution of the good, the good would be taken from the interested person and it would be returned to the injured person; the bona fide interested person from whom the good was taken, he has the right to ask for the restitution of the sum he had paid as a price to the doer; in the same situation, the mala fide interested person has no right to ask the price's restitution and consequently the respective sum will be seized from the doer ${ }^{35}$.

The matter of the seizure of the goods obtained by the deed provided in the penal law it's raised only when the injured person doesn't request their restitution or compensations (the goods' equivalent); this legal provision is contained by the final part of article 118 letter e. of the Penal Code and also it was accepted by the case-law ${ }^{36}$.

The justification of the seizure of the goods obtained by the deed provided by the penal law it consists in the necessity to eliminate the state of danger which is represented by the doers that possess such goods because they can utilize them or they can put back them in circulation or they can keep the offence's benefit, fact which is not only illegal, but also immoral $^{37}$.

To dispose the seizure of the "produced goods" it's not necessary that the deed should be an offence, but it's enough that the deed should be provided by the penal law. Consequently, the seizure of the good which was stolen by an irresponsible it could be disposed, if the injured person didn't ask for its restitution or for civil compensations.

f. The goods of which possession is prohibited by law

According to article 118 letter $\mathrm{f}$. of the Penal Code, all the goods of which possession is prohibited by law there are submitted to the special seizure; this means that the state of danger represented by their possession doesn't have to be proved because it's presumed by the legislator.

Sometimes, by certain dispositions or by special laws it's provided that the illegal possession of certain goods it's incriminated as an offence on its own, as it would be for instance: the possession of the fire arms and of ammunitions, without authorization; explosive or radio-active materials; abortion instruments; poaching tools and others.

In most cases, the goods possessed against the law dispositions "are produced" by the deed stipulated in the penal law (for instance, the possession of goods introduced by contraband in the country, the possession of arms or of explosive materials made illegally, the possession of false coins and others) or these goods "served" for the perpetration of some deeds provided by the penal law (for instance, fire arms, explosive materials, devices for the coins' falsification, narcotics and others ${ }^{38}$ ).

When a good which is presumed to be dangerous, for instance, a fire arm for which the doer has an authorization of possession, it was utilized for the perpetration of an offence, its seizure would have as a legal ground the provisions of article 118 letter $\mathrm{f}$. of the Penal Code.

The seizure of the goods of which possession is prohibited by law is disposed no matter if the respective good belongs to the doer or to other person, even if this person has no contribution to the perpetration of the deed provided by the penal law. If the good (an arm) was legally owned by the proprietor and the doer obviously purloined the good from him, it

\footnotetext{
35 The Supreme Tribunal, Penal Decision number 816/1985, R.R.D. number 4/1984, p. 72. The Supreme Tribunal, Penal Decision number 64/1986, R.R.D. number 6/1987, p. 76.

${ }^{36}$ The Supreme Tribunal, Penal Decision number 376/1981, R.R.D. number 11/1981, p. 60.

${ }^{37}$ M. Vasile, Aspecte particulare in materia confiscării speciale în ceea ce priveşte cazurile de aplicare, "Dreptul" Review, number 3/2003, p. 135.

${ }^{38}$ V. Papadopol, Confiscarea specială în practică judiciară, R.R.D. number 5/1983, p. 47.
} 
will be disposed the restitution and not the seizure; the restitution is made to the person from whom the good was purloined, at her request ${ }^{39}$.

\section{Conclusions}

The penal law can act more efficiently against the criminality by using not only the system of punishments (retributive and repressive sanctions) but also complementary means, with a preventive character, respectively, the safety measures that can be enforced by the judiciary bodies when the perpetration of a deed provided by the penal law it's established.

The social jeopardy, the state of danger which such goods would present if they were let at the doer's free disposal and he would be tempted to utilize them in order to commit new deeds provided by the penal law, thus these goods have to be eliminated by the special seizure's enforcement.

As the other safety measures, the special seizure is a penal law sanction because it intervenes only for the persons that committed a deed provided by the penal law; at the same time, it's a legal measure and it represents the appliance of the principle "nulla poena sine lege".

But, in comparison with other safety measures, the special seizure has to be accompanied by a punishment and in its enforcement, the general criteria of individualisation provided by article 72 of the Penal Code are not taken into consideration, but there are taken into account the nature and the gravity of the state of danger and the possibilities to eliminate it.

\section{Bibliography}

M. Vasile, Aspecte particulare în materia confiscării speciale în ceea ce priveşte cazurile de aplicare, "Dreptul" Review, number 3/2003;

M. Vasile, Aspecte particulare în materia confiscării speciale în ceea ce priveşte cazurile de aplicare, "Dreptul" Review, number 3/2002;

J.F. Popa, Măsura de siguranță a confiscării speciale prevăzută de art. 118 lit. b., Cod penal cu referire specială la confiscarea vehiculelor, "Dreptul" Review, number 6/2000;

C. Niculeanu, Confiscarea specială. Sume de bani obținute prin valorificarea bunurilor dobândite prin infracțiune, "Dreptul" Review, number 4/1999;

R. Chiriță, Câteva considerații în legătură cu temeiul juridic al aplicării măsurilor de siguranță, "Dreptul" Review, number 1/1999;

V. Pasca, Măsurile de siguranță, "Lumina Lex” Publishing House, Bucharest, 1998;

S. Aragea, Confiscarea specială în practica judiciară, Pro lege number 1/1991;

C. Turianu, I. Mihai, Examen teoretic al practicii judiciare cu privire la aplicarea măsurii de siguranță a confiscării, R.R.D. number 5/1987;

M. Basarab, Aspecte teoretice şi practice privind confiscarea specială în lumina art. 118, lit. b, Cod penal, Studia Universitatea, Babeş Bolyai, Jurisprudentia XXXII, number 2/1987;

V. Papadopol, Confiscarea specială în practica judiciară, R.R.D. number 5/1983;

C. Dărîngă, Privire generală asupra măsurilor de siguranță, R.R.D. number 1/1967.

\section{Case-law}

The Supreme Tribunal, Penal Decision number 64/1986, "Revista Romana de Drept (R.R.D.)" Review, number 6/1987;

The Supreme Tribunal, Penal Decision, number 2973/1985, R.R.D. number 12/1986;

The Supreme Tribunal, Penal Decision number 3074/1985, R.R.D. number 9/1986;

The Supreme Tribunal, Penal Decision number 54/1985, R.R.D. number 7/1986;

Tribunal of Bucharest, Penal Decision number 2279/1984, R.R.D. number 3/1986;

\footnotetext{
${ }^{39}$ V. Pasca, Măsurile de siguranță, Lumina Lex Publishing House, Bucharest, 1998, p. 244.
} 
The Supreme Tribunal, Penal Decision number 798/1985, R.R.D. number 2/1986; The Supreme Tribunal, Penal Decision number 1578/1984, R.R.D. number 10/1985; The Supreme Tribunal, Penal Decision number 614/1984, R.R.D. number 2/1985; The Tribunal of Maramures, Penal Decision number 91/1984, R.R.D. number $11 / 1984$

The Supreme Tribunal, Penal Decision number 816/1985, R.R.D. number 4/1984; The Tribunal of Bucharest, Penal Decision number 2489/1984, Repertoriu number 3; The Tribunal of Bucharest, Penal Decision number 298/1983, Repertoriu number 3; The Supreme Tribunal, Penal Decision number 376/1981, R.R.D. number 11/1981; The Supreme Tribunal, Penal Decision number 276/1981, R.R.D. number 11/1981; The Tribunal of Timis, Penal Decision number 696/1980, R.R.D. number 7/1981; 1980 ;

The Supreme Tribunal, Penal Decision number 841/1980, "Culegere de decizii",

The Supreme Tribunal, Penal Decision number 945/1980, "Repertoriu" number 2; 1979;

The Supreme Tribunal, Penal Decision number 1822/1979, "Culegere de decizii",

The Supreme Tribunal, Penal Decision number 473/1978, R.R.D. number 8/1978;

The Supreme Tribunal, Penal Decision number 448/1977, R.R.D. number 12/1977;

The Supreme Tribunal, Guidance Decision number 3/1973, R.R.D. number 6/1973;

The Supreme Tribunal, Penal Decision number 2559/1972, R.R.D. number 2/1973;

The Supreme Tribunal, Penal Decision number 3622/1972, "Repertoriu", number 1; 1971 ;

The Supreme Tribunal, Penal Decision number 1647/1971, "Culegere de decizii",

The Supreme Tribunal, Penal Decision number 464/1978, R.R.D. number 3/1969. 